УДК 023.5: 004.9(73)

Філіпова Людмила Яківна, доктор педагогічних наук, професор, професор кафедри інформаційних технологій

Харківської державної академії культури

flyak@ukr.net

ORCID 0000-0003-0273-7922

Олійник Ольга Вімалї̈вна, кандидат наук із соціальних комунікацій, доцент, доцент кафедри іноземних мов Харківської державної академії культури oliynykhelga@gmail.com

ORCID 0000-0002-4224-7269

\title{
ТРАНСФОРМАЦІЙНІ ХАРАКТЕРИСТИКИ ПРОФЕСІЙНОЇ ДІЯЛЬНОСТІ АМЕРИКАНСЬКИХ БІБЛІОТЕКАРІВ В УМОВАХ ІНТЕРНЕТ-КОМУНІКАЦІЙ
}

\begin{abstract}
Мета статmі - характеристика професійних якостей праиівників американських бібліотек в інформаційному суспільстві під впливом впровадження комп 'ютерних та Інтернет-технологій; аналіз факторів впливу інтернет-комунікацій на зміни акцентів професійної діяльності американських бібліотекарів та взагалі бібліотечної професії на міжнародному рівні. Методологія дослідження полягає в застосуванні загальнонаукових та спеціальних методів, зокрема системного та порівняльного підходів, а також проблемного та аналітичного аналізу для вивчення принципів та тендениій розвитку бібліотечної професії у вищих навчальних закладах США. Наукова новизна роботи полягає у тому, що здійснено аналіз професійних якостей працівників американських бібліотек в умовах впровадження інтернет-технологій; охарактеризовано базові характеристики професійної компетентності бібліотекарів, які перетворилися на інформачійно-комп'ютерні та інформаційнокомунікаційні компетениії бібліотечної професії, щзо дозволяє їм опановувати технологічний рівень професії та формувати освітні стандарти та вимоги у вищих бібліотечно-інформачійних школах США. Висновки. Перехід американських бібліотек на інформаційно-технологічну платформу суттєво вплинув на професійну діяльність бібліотечних прачівників, статус яких в інформачійному американському суспільстві є достатньо високим. Відзначається зростаючий вплив на професійну діяльність бібліотекарів комунікаиійних та інформаиійних технологій, суттєво розиирюються професійні компетенції бібліотекарів, досягаючи рівня висококваліфікованих користувачів комп 'ютерних систем і мереж, навіть з певними функиіями адміністрування бібліотечних баз даних та інформаційних систем.
\end{abstract}

Ключові слова: професійна діяльність бібліотекарів, комп'ютерні та інтернет-технології, інформачійні компетенції бібліотечної професії, США.

Филиппова Людмила Яковлевна, доктор педагогических наук, профессор, профессор кафедры информационных технологий Харьковской государственной академии культуры

Олейник Ольга Витальевна, кандидат наук по социальным коммуникациям, доцент, доцент кафедры иностранных языков

Харьковской государственной академии культуры

\section{ТРАНСФОРМАЦИОННЫЕ ХАРАКТЕРИСТИКИ ПРОФЕССИОНАЛЬНОЙ ДЕЯТЕЛЬНОСТИ АМЕРИКАНСКИХ БИБЛИОТЕКАРЕЙ В УСЛОВИЯХ ИНТЕРНЕТ-КОММУНИКАЦИЙ}

Цель статьи - характеристика профессиональных качеств работников американских библиотек в информационном обществе под влиянием внедрения компьютерных и Интернет-технологий; анализ 
факторов влияния интернет-коммуникаций на изменения акиентов профессиональной деятельности американских библиотекарей и всей библиотечной профессии на международном уровне. Методология исследования заключается в применении общенаучных и специальных методов, в частности системного и сравнительного подходов, а также проблемного и аналитического анализа для изучения принципов и тенденций развития библиотечной профессии в высших учебных заведениях США. Научная новизна работы заключается в том, что осуществлен анализ профессиональных качеств работников американских библиотек в условиях внедрения интернет-технологий; охарактеризованы базовые характеристики профессиональной компетентности библиотекарей, которые превратились в информационно-компьютерные и информационно-коммуникационные компетенции библиотечной профессии, что позволяет им овладевать технологическим уровнем профессии и формировать образовательные стандарты и требования в высших библиотечно-информационных школах США. Выводы. Переход американских библиотек на информационно-технологическую платформу существенно повлиял на профессиональную деятельность библиотечных работников, статус которых в информационном американском обществе достаточно высок. Отмечается возрастающее влияние на профессиональную деятельность библиотекарей коммуникационных и информационных технологий, существенно расширяются профессиональные компетенции библиотекарей, достигая уровня высококвалифицированных пользователей компьютерных систем и сетей, с определенными функциями администрирования библиотечных баз данных и информационных систем.

Ключевые слова: профессиональная деятельность библиотекарей, компьютерные и интернеттехнологии, информачионные компетенщии библиотечной профессии, США.

Filipova Liudmyla,

Doctor of Sciences (Pedagogical), Professor

Kharkiv State Academy of Culture

Oliinyk Olga, $\mathrm{PhD}$, Associated Professor, Kharkiv State Academy of Culture

\section{TRANSFORMATION CHARACTERISTICS OF PROFESSIONAL ACTIVITY OF AMERICAN LIBRARIANS UNDER THE CONDITIONS OF INTERNET- COMMUNICATIONS}

The purpose of the article is to characterize the professional qualities of American library workers in the information society under the influence of the introduction of computer and Internet technologies; analysis of the factors of the influence of Internet communications on changes in the emphasis of the professional activities of American librarians and the entire library profession at the international level. Methodology consists of the application of general scientific and special methods, in particular, systematic and comparative approaches, as well as problematic and analytical analysis to study the principles and trends of the library profession in US universities. Scientific novelty of the work lies in the fact that the analysis of the professional qualities of employees of American libraries in the implementation of Internet technologies; the basic characteristics of the professional competence of librarians are described, which have turned into information-computer and information-communication competencies of the library profession, which allows them to master the technological level of the profession and form educational standards and requirements in higher library and information schools of the United States. Conclusions. The transition of American libraries to the information technology platform has significantly affected the professional activities of library workers, whose status in the American information society is quite high. There is a growing influence on the professional activities of librarians of communication and information technologies, the professional competencies of librarians are expanding significantly, reaching the level of highly qualified users of computer systems and networks, with certain functions of administering library databases and information systems.

Key words: professional activities of librarians, computer and Internet technologies, information competencies of the library profession, USA 
Актуальність теми дослідження. Інформатизація бібліотек $є$ одним із пріоритетних напрямів у сфері культури на міжнародному рівні. Її ключовим елементом є об'єднання інтелектуальних, інформаційних і технологічних ресурсів усіх бібліотек незалежно від їхньої відомчої підпорядкованості. Формується нова інформаційна інфраструктура, де бібліотеки - іï важлива складова. Особливого значення набувають інформаційно-комунікаційні технології (ІКТ) та інтернет-технології, використання яких поширює доступ до світових досягнень культури через електронні ресурси та сервіс.

Інформатизація впливає на бібліотечну діяльність через не лише технічні та технологічні засоби, а й змістовно-інформаційні засоби передання знань, відомостей. Тобто спостерігається якісне поліпшення та збільшення обсягів інформації на різних носіях і рівнях. Відбувається процес «семіотизації» суспільства - розвиток численних знакових систем, завдяки яким формується багатокомпонентне «інформаційне поле», яке являє собою інформаційне оточення людини (поєднання текстів, графічного зображення, знакових і аудіовізуальних відомостей тощо). Виникає проблема інформаційно-комунікативної адаптації людини в сучасному суспільстві.

Подібні тенденції спостерігалися й в американському бібліотечному середовищі, зокрема вони вплинули на розвиток академічних бібліотек. Усі ці зміни зумовили посилення вимог до бібліотек ще наприкінці минулого сторіччя і зробили певний внесок у формування єдиної думки про те, що бібліотека є «серцем» будь-якої важливої академічної установи [8]. Відзначається ще один важливий фактор сприяння розвиткові академічних бібліотек це професійне зростання в цій сфері. Заснування Американської Бібліотечної Асоціації (ALA) і діяльність деяких енергійних та шановних бібліотечних адміністраторів, таких як Мелвіл Дьюї (Колумбія) і Джастін Вінзор (Гарвард), ознаменувало виникнення нового класу - професійних бібліотекарів.

Мета статті-охарактеризувати професійні характеристики американських бібліотекарів в умовах інформаційного суспільства, які перетворилися на інформаційно-комп'ютерні та інформаційно-комунікаційні компетенції бібліотечної професії.

Аналіз досліджень і публікацій. Аналізуючи професійні якості американських бібліотечних працівників, фахівці підкреслюють, що одним 3 найважливіших факторів бібліотечного розвитку стало зростаюче значення інформаційних технологій у роботі бібліотек США. Американські дослідники Б. Кронін та Л. Шифлет акцентують увагу на те, що повсюдне впровадження новітніх інформаційних технологій у бібліотеках стає одним 3 найперспективніших напрямів розвитку [9]. У другій половині XX ст. відбулися важливі зміни в бібліотечній практиці; інформаційна революція потребувала нових технічних рішень для підтримки ефективності традиційних бібліотечних систем і процесів. Нині технологічний та організаційний рівні розвитку бібліотечних і інформаційних послуг, наданих бібліотеками США, формують вимоги до організації навчального процесу у вищих бібліотечно-інформаційних школах США. Випускники цих шкіл повинні вміти працювати з будь-якими технічними засобами та програмним забезпеченням, що застосовуються нині і використовуватимуться в бібліотечноінформаційних системах протягом найближчих років.

Наукові та прикладні статті й доповіді американських фахівців висвітлюють особливості та прогрес використання комп'ютернокомунікаційних технологій в окремих бібліотечних процесах, підрозділах, системах, комплексах; становлять підгрунтя для розуміння факторів розвитку бібліотечної практики в США. Більшість авторів виділяли окремі аспекти цього процесу, зокрема роль і місце інформаційних технологій у бібліотечній практиці (St. Lifer E., Jacso P., Roosa M., Hans R., Breeding M., Cronin B. та ін.). Численні публікації щодо сучасних вимог до американських бібліотекарів від роботодавців можна знайти на сайтах професійних організацій: Американської бібліотечної асоціації (ALA), Асоціації коледжів та наукових бібліотек (ACRL), Асоціації бібліотек та інформаційних технологій (LITA) та інших [10]. У них акцентовано на наявності досконалого володіння бібліотекарями засобами IT та інтернет-комунікацій 
для виконання бібліотечного керівництва, консультування та обслуговування на основі електронних мережевих ресурсів та сервісів.

Виклад основного матеріалу дослідження. Сучасним бібліотекам США належить провідна роль в опануванні нових інформаційних технологій. Серед головних тенденцій сучасного розвитку американських бібліотек уважається становлення і розвиток професійних кадрів - бібліотечно-інформаційних фахівців.

Інформатизація американського суспільства значною мірою вплинула на бібліотечну галузь, як зазначалося вище, завдяки успішному впровадженню IКТ та інтернеттехнологій. Головним учасником бібліотечноінформаційної діяльності є бібліотечний професіонал. Слід підкреслити, що прогнози про майбутнє бібліотеки у зв' язку зі здобуттями інформатизації грунтувалися на судженнях про архаїчність бібліотеки, неможливість ії трансформації. Завдяки активній комп'ютеризації публічних та університетських, а згодом й інших бібліотек, відбулися незворотні технологічні зміни, які набули поширення, як і професія бібліотекаря. Фахівці, які впорядковують інформацію, здійснюють інтерактивний пошук, консультують і навчають користувачів комп'ютерної грамотності та культури, виявилися затребуваними в інформаційному суспільстві. Участь бібліотекарів в упровадженні сучасного варіанта технології інформування довела, що найважливішими професійноособистісними рисами бібліотекарів є: володіння метазнаннями (знаннями про те, як здобувати знання); діалогічність мислення; метакогнітивність (здатність формулювати запит на пошук, навіть за умов нечіткого його розуміння читачем) [9].

Бібліотечно-інформаційна сфера, що постійно й активно розширюється та змінюється, потребує безперервної комп'ютерної і технологічної самоосвіти, раціоналізації, розвитку нових напрямів професійної культури бібліотекаря.

Американські дослідники відзначають еволюційні процеси в бібліотечній профеciï США. Ще в 1996 р. американський журнал «Library Journal» провів репрезентативне опитування бібліотечних працівників, щоб з'ясувати, на якому рівні й у якому напрямі еволюціонує бібліотечна професія в сучасному суспільстві, визначити масштаби змін, їхні причини і вплив на повсякденну практику бібліотечної роботи, а також на сприйняття бібліотекарями своїх нових професійних ролей і нового статусу бібліотечної спеціальності в суспільстві. В опитуванні взяли участь більше 1000 співробітників бібліотек різних типів iз різних регіонів США, що повідомили про кардинальні зміни у своїй професійній діяльності, пов'язані насамперед з використанням нових технологій [12].

За результатами цього опитування, бібліотекарі відзначили зростаючий вплив на свою професійну діяльність телекомунікаційних та інформаційних технологій; безупинний розвиток і вдосконалення сприяють постійному збільшенню обсягу інформації, що поширюється комп'ютерними мережами, насамперед в Інтернеті, який називають також інформаційною супермагістраллю. Більшість бібліотекарів 3 ентузіазмом ставились до можливостей, що надають інформаційні мережі, i активно долучаються до дослідження й формування нового інформаційного середовища. Вони $є$ не лише так званими «навігаторами» по інформаційних ресурсах Інтернету, але i навчають роботі в мережі читачів бібліотеки, своїх колег; стають не просто користувачами, але й забезпечують інформаційне супроводження та наповнення мережевих продуктів, опановуючи функції адміністраторів баз даних (БД) та інформаційних систем (IC). Крім зазначених вище напрямів діяльності, респонденти назвали такі функції, що пов'язані з використанням інформаційних мереж: створення і оновлення веб-сторінок; електронна видавнича діяльність; участь у професійних телеконференціях і дискусійних групах; проведення тренінгів 3 роботи в Інтернеті для співробітників і читачів бібліотек. Бібліотекарі розуміють важливість набуття необхідних для роботи з електронними документами навичок 3 метою вирішення на новому технологічному рівні основних завдань бібліотечної діяльності, а саме: виявлення, оцінки, організації і забезпечення доступу до всього різноманіття інформаційних ресурсів відповідно до потреб користувачів [12]. 
Американські бібліотекарі проводять також активну роботу поза межами бібліотеки стосовно пропаганди інформаційних ресурсів мереж і бібліотек як посередників між джерелами і споживачами інформації. Бібліотекарі назвали такі форми роботи 3 населенням: лекції і виступи про Інтернет у громадських організаціях і культурно-освітніх установах; підготовка, проведення й участь у семінарах і практикумах; проведення Дня Інтернету в школах та інших навчальних закладах; участь у суспільних інформаційних мережах тощо. Подібні заходи покликані убезпечити бібліотечну професію від жахливої перспективи бути витісненою на узбіччя інформаційної супермагістралі. У зв'язку з цим правомірно говорити не лише про зміну службових обов'язків, але й про еволюцію соціальних ролей і функцій бібліотекарів. Хоча більшість бібліотекарів, що заповнили анкету, вважає розширення сфери своєї діяльності «захоплюючим», «мобілізуючим» чи «значним прогресом», деякі респонденти сумніваються в адекватності своїх знань і навичок, відзначають труднощі в опануванні нових інформаційних технологій. У результаті бібліотекарі прагнуть брати активну участь у програмах з професійного навчання і перепідготовки: 73\% опитаних співробітників публічних бібліотек, 69\% вузівських і $68 \%$ спеціальних бібліотек розробляли певні програми безперервної професійної освіти. Серед форм навчання найчастіше згадуються тренінги в Інтернеті та навчання комп'ютерної грамотності [12].

На думку респондентів, для роботи в бібліотеці необхідні грунтовніші, ніж базові, знання з роботи в інтернет-просторі. Найпідготовленішими до такої роботи виявилися нещодавні випускники бібліотечних коледжів, що здобули знання в галузі інформаційних i телекомунікаційних технологій відповідно до нових навчальних програм. Таким чином, молодим фахівцям часто належить провідна роль в опануванні технологічних нововведень. Однак етап, на якому вміння працювати в Інтернеті розглядалося як спеціальна професійна навичка, у США, очевидно, уже минув. У деяких бібліотеках посада бібліотекаря-консультанта 3 інформаційно-бібліографічного обслуговування передбачає, що цей співробітник ін- тенсивно працює в Інтернеті. Частково це зумовлено специфікою роботи бібліотекарів цієї спеціалізації, однак інтернет-грамотність однаковою мірою необхідна і каталогізаторам, i бібліотекарям, що працюють 3 дітьми, і співробітникам інших підрозділів бібліотеки.

Більшість опитаних бібліотекарів позитивно сприймають зміни, що відбуваються, однак по-різному оцінюють готовність бібліотечного керівництва до підтримки своїх працівників у нових умовах. У деяких бібліотеках впроваджуються нові посади (наприклад, «координатор бібліотечно-інформаційних систем», «бібліотекар з інформаційних технологій») або переглядаються існуючі посадові інструкції із зазначенням додатково виконуваних видів робіт. Як свідчать результати опитування, професійні навички роботи в Інтернеті забезпечують найкращі перспективи службового зростання для бібліотекарів зі ступенем магістра бібліотекознавства.

Бібліотекарі, які відповіли на запитання «Library Journal», вважають основними факторами, що впливають на еволюцію своєї професії, швидкий розвиток технологій і скорочення фінансування. Попри проблеми, пов'язані 3 опануванням нових технологій, недостатнім фінансуванням, неадекватною оплатою праці й неукомплектованістю штатів, 90\% бібліотекарів задоволені своєю роботою [12].

Успіх розвитку бібліотечної справи суттєво залежить від підготовки бібліотечних кадрів, спостерігається і зворотна залежність, тобто сучасний рівень розвитку бібліотечної справи в США задає певні стандарти і вимоги до бібліотечно-інформаційних вищих шкіл щодо підготовки фахівців. Їхні випускники мають працювати 3 будь-якими технічними засобами і програмним забезпеченням, яке використовується в бібліотечно-інформаційних системах протягом останніх років [5].

Перехід бібліотек різного типу на інформаційно-технологічну платформу суттєво вплинув на професійну діяльність бібліотечних працівників, статус яких в інформаційному американському суспільстві $є$ доволі високим. Відзначається зростаючий вплив на професійну діяльність бібліотекарів комунікаційних й інформаційних технологій, безупинний розвиток і вдосконалення яких сприяють 
постійному збільшенню обсягу інформації, що поширюється в комп'ютерних мережах, насамперед в Інтернеті. Оскільки бібліотеки перетворюються на освітньо-інформаційні центри, то, відповідно, змінюється рівень професіоналізму бібліотекарів. Уміння навчати користувачів, шукати в Інтернеті та мати систематичні знання в галузі веб-дизайну стає стандартною вимогою до кваліфікації бібліотекаря [7].

Можна відзначити, що нині зникають відмінності між фахівцями в галузі комп'ютерних технологій і бібліотечними фахівцями як висококваліфікованими користувачами комп'ютерних систем і мереж. Суттєво розширюється професійна компетенція бібліотекарів, тобто їхні повноваження, знання, уміння та навички, роль у сучасних процесах освіти, науки, практики.

Логічним продовженням аналізу трансформаційних процесів у бібліотечній професії має стати звернення до положень бібліотечної професіології, які обгрунтовані в численних наукових працях, і головна увага акцентується на розширенні компетенції цієї професії в умовах інформатизації суспільства.

Отже, з урахуванням прикладу сучасних американських бібліотечних фахівців, можна констатувати, що головними професійними якостями в межах їхньої професійної компетентності $є$ інформаційна та комунікативна компетентність. Інформаційна компетентність бібліотекаря характеризується знаннями, вміннями й навичками самостійного творчого пошуку, аналізу, обробки, організації, змін, збереження, передачі, поширення будьякої інформації, на базі опанування сучасних інформаційно-комунікаційних технологій. Комунікативна компетентність характеризується знаннями, вміннями та навичками налагодження, підтримки і розвитку ефективної взаємодії з читачами або іншими учасниками бібліотечного процесу. Можна зазначити, що базовими характеристиками професійної компетентності американських бібліотекарів стали інформаційна та комунікативна компетентність, які реалізуються на рівні їхніх професійно-діяльнісних функцій. Бібліотечні фахівці здатні і зможуть вільно використовувати будь-які комп'ютерні й інтернеттехнології та сервіси, мають удосконалювати свою фахову майстерність на базі інноваційних технологій, розвивати вміння консультування та навчання читачів/користувачів, набувати навичок міжособистісних комунікацій i саморозвитку.

Аналіз сучасного розвитку бібліотечної практики США та бібліотечної професії доводить, що технологічний рівень розвитку бібліотек та відповідні якості професійної компетентності бібліотекарів формують відповідні стандарти та вимоги до освітнього процесу у вищих бібліотечно-інформаційних школах США.

Висновки. Отже, перехід американських бібліотек на інформаційно-технологічну платформу суттєво вплинув на професійну діяльність бібліотечних працівників, статус яких в інформаційному американському суспільстві є достатньо високим. Відзначається зростаючий вплив на професійну діяльність бібліотекарів комунікаційних та інформаційних технологій, безупинний розвиток і вдосконалення яких сприяють постійному збільшенню обсягу інформації, що поширюється в комп'ютерних мережах, насамперед в Інтернеті. Оскільки бібліотеки перетворюються на освітньо-інформаційні центри, то, відповідно, змінюється рівень професіоналізму бібліотекарів. Уміння навчати користувачів, вести пошук в Інтернеті та мати систематичні знання в галузі веб-дизайну стає стандартною вимогою до кваліфікації бібліотекаря. Суттєво розширюються професійні компетенції бібліотекарів, досягаючи рівня висококваліфікованих користувачів комп'ютерних систем і мереж, навіть 3 певними функціями адміністрування бібліотечних БД та IC. 


\section{Список використаних джерел}

1. Конюкова І. Я. Розвиток бібліотечної професії в Україні: сучасні концепції та напрями : автореф. дис. на здобуття наук. ступеня канд. пед. наук: 07.00.08 / Київ. нац. ун-т культури і мистец. К., 2002. $20 \mathrm{c}$.

2. Равен Дж. Компетентность в современном обществе: выявление, развитие и реализация : пер. с англ. М. : Когито-Центр, 2002. 396 с.

3. Чачко А. С. Современная библиотека в процессе трансформаций : монография. К., 2003. 140 c.

4. Breeding M. Capturing the Migrating Customer // Library Journal. 2002. Vol. 127, № 6. P. 48-54.

5. Continuing professional development: pathways to leadership in the library and information world / ed. by Ann Ritchie, Clare Walker. München : Saur, 2007. 319 c.

6. Cronin B. The Dean's List: What a Library Is Not // Library Journal. 2002. Vol. 127, № 19. P. $46-47$.

7. Hans R. Digital Libraries and Education. Trends and Opportunities // D-Lib Magazine. 2001.V. 7, N $7 / 8$.

8. Harris M. H. History Of Libraries In The Western World // The Scarecrow Press, Inc. Lanham, Maryland, and London, 1999. 299 p.

9. Jacso P. What Is Digital Librarianship // Computers in Libraries. 2000. Jan. P. 54-55.

10. Jobs in Library \& Information Science \& Technology (2019). Retrieved from https://joblist.ala.org/j obs $/$ ?str $=26 \& \max =25 \&$ long $=1 \&$ vnet $=0$

11. Roosa M. Library of Congress for digital future // International Preservation News. 2008. № 22/23. P. 32.

12. St. Lifer E. Net work: new roles, same mission // Library Journal. 1996. Vol. 121, № 19. P. 26-30.

\section{References}

1. Konyukova, I. I. (2002). Development of library profession in Ukraine: modern concepts and directions. Extended abstract of candidate's thesis. K.: KyivNUCA [in Ukrainian].

2. Raven, J. (2002). Competence in modern society: identification, development and implementation. M.: Kogito-Centr. [In Russian].

3. Chachko, A. S. (2003). The modern library in the process of transformation. Kyiv. [In Russian].

4. Breeding M. Capturing the Migrating Customer (2002). Library Journal. Vol. 127, № 6. P. 48-54. [in English].

5. Continuing professional development: pathways to leadership in the library and information world (2007). München : Saur. 319 s. [in English].

6. Cronin B. (2002). The Dean’s List: What a Library Is Not. Library Journal. Vol. 127, № 19. P. 46-47. [in English].

7. Hans R. (2001). Digital Libraries and Education. Trends and Opportunities. D-Lib Magazine.V. 7, N 7/8. [in English].

8. Harris M. H. (1999). History Of Libraries In The Western World. The Scarecrow Press, Inc. Lanham, Maryland, and London. 299 p. [in English].

9. Jacso P. (2008). What Is Digital Librarianship. Computers in Libraries. Jan. P. 54-55. [in English].

10. Jobs in Library \& Information Science \& Technology (2019). - URL: https://joblist.ala.org/jobs/?s tr $=26 \& \max =25 \&$ long $=1 \& v n e t=0$ [in English].

11. Roosa M. (2007). Library of Congress for digital future. International Preservation News. № 22/23. P. 32. [in English].

12. St. Lifer E. (1996). Net work: new roles, same mission. Library Journal. Vol. 121, № 19. P. 26-30. [in English]. 